\title{
Psychological Needs as the Working-Life Quality Predictor of Special Education Teachers
}

\author{
Hasan Bozgeyikli \\ Faculty of Education, Erciyes University, Turkey
}

Copyright $(\mathrm{C} 2018$ by authors, all rights reserved. Authors agree that this article remains permanently open access under the terms of the Creative Commons Attribution License 4.0 International License

\begin{abstract}
The purpose of this research is to determine whether psychological needs that the special education teachers have, significantly predict the professional quality of life. Descriptive survey design was used in the research. The data of the research were obtained from 238 special education teachers (45\% males and $55.5 \%$ females) who were working as a special education teacher in the schools affiliated to the Ministry of National Education in Kayseri in 2017 and were selected by simple random sampling method. 69.7\% (166 people) of the special education teachers who participated in the research were married, and $30.3 \%$ (72 people) of them were unmarried. In the research, professional quality of life and the psychological needs levels of special education teachers were measured by "Professional quality of life scale" and "New psychological needs scale," respectively. Pearson correlation technique and multiple linear regression analysis were used to analyze the collected data. The results of the research showed that there was a positive significant relationship between the burnout levels of special education teachers' and their psychological needs (success, relationship, autonomy, and dominance needs) and that there was a negative relationship between compassion satisfaction and compassion fatigue. According to the findings obtained as a result of the predictive analyses, the autonomy, relationship, and dominance, which are the sub-dimensions of the psychological needs scale, were found to be the most important predictors of special education teachers' professional life quality. The results obtained from the research were discussed within the scope of the relevant literature, and proposals were made for future researches.
\end{abstract}

Keywords Special Education Teachers, Professional Quality of Life, Psychological Needs, Prediction

\section{Introduction}

People spend a great amount of their life on work and some of the rest thinking about their work. Therefore, work has a profound impact on one's whole life. The pleasure people get from their work and its positive effect on his/her life gradually poses its favourable influences on physical health as well as the psychological one, yielding happiness within the family and efficiency in the workplace [1]. In other words, self-satisfaction in the workplace has great influence on not only the working life but also life satisfaction in a general sense. Working life quality refers to the state of being content or discontent one experiences in the working atmosphere, which have such three sub-divisions as compassion satisfaction, professional exhaustion or burnout and compassion fatigue [2].

While many hardships encountered in the professional life deteriorate quality of life, improvements in the professional satisfaction levels (compassion satisfaction) enhance it. Professional satisfaction can be described as the feeling of pleasure, content and please felt as a result of providing help for someone in need related to the professional' branch [2]. The studies concerning professional satisfaction have indicated the level of professional satisfaction $[3 ; 4 ; 5]$ has an influence on both physical and psychological well-being of individuals. According to Sevimli \& İscan [6], while the satisfaction gained from the workplace reflects itself favourably in other fields of life, discontent and disappointment as well as reluctance have an adverse impact on the pleasure taken from life. Exposure to such adverse conditions in the workplace can also be handled as exhaustion. When analysed, the studies in the literature have suggested that professional dissatisfaction has something to do with stress and exhaustion. In other words, the low level of professional satisfaction results in professional exhaustion. Today, the most widely accepted definition of exhaustion is the one with three components developed by Maslach [11]. In accordance with this definition, exhaustion is a three dimensional concept in which emotional exhaustion, depersonalization and personal accomplishment are seen widely in people who work with others in person $[12 ; 13$; $14 ; 15]$. 
The teaching profession considered as one of the most stressful occupations, becomes more stressful when it comes to the education of children with disabilities because of the personal characteristics of these children. Particularly, depending on the intensity of the direct contact with the students, it is stated that the special education teachers are more likely to be burnout than the other teachers. [16]. In this respect, training special children is one of the most jeopardized professions by stress and exhaustion which cause dissatisfaction in turn. Other factors behind the dissatisfaction and exhaustion of special education teachers are the lack of materials, excessive formalities, being neglected and much interaction with stressful people such as family members and managers [17]. In such services as teaching special children devoted to handicapped individuals, frequent exposure to traumatic incidences as an expected outcome of such kind of professions render these instructors more susceptible to psychological problems [1]. This condition is called 'compassion fatigue' which is another factor handled within the scope of life quality. The state before which an individual is exposed to a stressful incidence is called compassion fatigue [2]. In accordance with the works within this field, among the factors concerning compassion fatigue such as whether the individual experienced a kind of trauma in advance or not, working hours, workload, physical conditions of the workplace and the service duration in the profession [18; 19] are observed to be the leading ones. Compassion fatigue and burnout which results from the former can cause a decline [20;21; $22]$ in the aid service quality provided by the employees in this profession. One of the primary reasons why special education teachers suffer from emotional exhaustion is that they engage both in the life of such children and in the problem solving process of them much more than required by an ordinary teacher figure. Such complications as compassion fatigue and exhaustion frequently encountered in teachers dealing with handicapped children whose education can be more demanding and require more patience engender economic loss, more layouts and quality deficiency as well as being the leading factors behind declining life quality [1].

One of the principal assumptions in the discipline of psychology states that there is always a need behind any act waiting to be met. This principal is also true for professional acts as well. While people are content with their professional career as long as they can meet their needs from the urgent to the simplest ones, they also expectedly develop discontent and a feeling of exhaustion in case their needs cannot be met accordingly. In this respect, another element directly influencing the quality of one's life is the notion of need. On the basis of acquiring a profession, apart from meeting the physiological need via money, social and psychological needs are also to be answered [23]. Therefore, professional satisfaction is, to some extent, related to satisfying the needs. A workplace that can satisfy the personal expectations of employees is considered to have a profound impact on enhancing life quality [24].

Needs can be described as physical and psychological patterns that emerge as a result of detecting a lack in one's disposition and change from person to person. These needs can be physiological ones such as shelter, breathe, water, food, sleep, sex etc. and they can be psychological ones such as love, affection, protection, success, learning and companionship [25]. Glasser [26] states that psychological needs that follow the physical ones await satisfaction once their compulsive physiological needs have been met. One of the two main processes underlying human practices and controlling their behaviour is the psychological needs [27].

Known as psychological needs, relationship, success, autonomy and dominance are also described by Heckert [28] as social ones. Being one of these needs, relationship is described as the desire for social interaction and recognition by others, whereas success is the want of being superior through better performance. This need refers to the desire for attempts to be superior in order to enhance current performance while autonomy is known as the desire for self-determinism with self-will of power and act in confidence [28]. The doctrine of self-determinism advocated that people can augment their motivation as to their business and adopt a better position subjectively on condition that they can meet their professional needs in a given institution or organisation. The theory of self-determinism advocates that people can enhance their motivation at the workplace and be at a better position on condition that they can satisfy their needs [29]. To illustrate, people can be as much healthy and feel better as they meet their needs of autonomy, competence and relationship [30]. It is evident that satisfying the psychological needs at the workplace contributes much to professional satisfaction as well as numerous favourable outcomes. In this sense, Kasser, Davey and Ryan [31] point out that people can increase their time for their jobs as much as they can meet their needs. Llardi, Leone, Kasser \& Ryan [32] revealed that workers at a factory had as much better appetite for their work, high level of self-respect and suffered less from diseases as they met their needs. Moreover, as long as individuals satisfied their needs at the workplace, they had better performance and they became psychologically well-conditioned [33]. In this respect, satisfying the psychological needs has favourable impact on functionality and quality of professional life.

Based on the works cited, a correlation is thought to exist between a special education teachers' life quality and his or her psychological needs. Accordingly, in this study conducted on special education teachers, it is intended to identify the correlation between the psychological needs and favourable compassion satisfaction, unfavourable burnout and compassion fatigue. In addition to this, the 
extent to which the level of psychological satisfaction determines the sub-dimensions of life quality is aimed to be determined. The findings of this study are thought to provide significant contributions, especially improving the quality of working life for these teachers, when considered the important role that special education teachers play in teaching disabled people.

\section{Materials and Methods}

In this study, in order to testify whether the psychological needs of special education teachers are the actual parameters of their working life quality, the method of this study was decided to be the descriptive survey model.

\subsection{Participants}

The participants of the study are the 238 special education teachers, $55 \%$ (131) of whom are women, $45 \%$ (107) are men working in Kayseri registered to Turkish Ministry of National Education. 69.7\% of them (166) were married while $30.3 \%$ (72) are single.

\subsection{Instruments}

Professional quality of life scale (ProQOLS): In order to measure the professional life quality of the participants' Professional quality of life scale (ProQOLS) developed by Stamm [2] and adapted to Turkish by Yeşil and others [34] was employed. Having a self-appraisal quality, ProQOLS comprises 3 sub-scales each of which have 10 terms, having a total of 30 terms. The first of the sub-scale, burnout is a test measuring hopelessness and exhaustion resulting from the difficulty coping with problems in working life. If the attribute in this scale is high, so is the level of exhaustion. The second is the scale of compassion satisfaction. In this scale, it is intended to measure the feeling of content and satisfaction felt when one helps someone in need of his or her professional help. A high property in this scale points the level of content and satisfaction in the eye of the helper. The third one, compassion fatigue scale, is a test devised to measure the indications arising from encountering stressful events. Participants with a high score in this scale are strongly advised to receive support. In the evaluation of the scales, a Likert style score ranging from 'never' $(0)$ and 'much frequent' (5) was employed. In the evaluation phase, 1, 4, 15,17 and $29^{\text {th }}$ terms are the ones graded backwards. The lowest level is 0 while the highest is 50 in each sub-scale. The alpha coefficients measured to determine the confidence coefficient is .87 for professional satisfaction, .72 for burnout and .80 for compassion fatigue [34]. The Alpha coefficients measured for this study are .82 for compassion satisfaction, .72 for burnout and .78 for compassion fatigue.

New Psychological Needs Scale (NPNS): Originally developed by Heckert et.al [2] to and adapted to Turkish by Kesici [35], 'New Psychological Needs Scale' was used to measure the psychological needs scale of the subjects. Being a means of self-report assessment, NPS comprises 20 terms and four sub-scales (success, relationship, autonomy and dominance), each of which have 5 terms. Success refers to the desire to be superior to others in order to perform better, whereas relationship refers to the need for social interaction and recognition within a given society. The need for autonomy encompasses the desire to do things for self rather than others while dominance includes the desire to be dominant on others. A high score in any of the sub-scales shows that the individual is devoid of that psychological need. Scale terms making up NPNS (except $8,14,18)$ are in the form of simple sentences. Cronbach Alpha internal coefficients measured based on the item analysis are .77 for success, .62 for relationship, .72 autonomy, .77 for dominance and .80 for the whole scale [35]. As for the alpha coefficients measured for this study are .78 for success, .72 for relationship, .79 for autonomy and .81 for dominance.

\subsection{Data Analysis}

For the analysis of the acquired data, Pearson correlation coefficients were initially computed in order to identify the relation between the sub-dimensions of psychological needs (success, relationship, autonomy and dominance) which make up the variants of the research and the ones of professional life quality (compassion satisfaction, burnout and compassion fatigue). Following that, so as to identify the regression level, interlinear regression analysis was employed. Significance level in this study was accepted as .05 .

\section{Findings}

In order to identify the correlation between the scores special education teachers acquired from the sub-dimensions of new psychological needs scale and the ones of professional life quality scale, the results of the Pearson Correlation analysis are given in the Table 1. When the correlation values analysed in Table 1 , it is evident that there is an avoidant significant correlation between need scores of success, relationship, autonomy, dominance, and compassion satisfaction, whereas a positive one exists between burnout and compassion fatigue. Based on, the findings, as the teachers' needs of success, relationship, autonomy, dominance, and compassion satisfaction rise, so do the levels of burnout and compassion fatigue, whereas the level of compassion satisfaction dwindles. 
Table 1. Pearson's correlation values regarding the relationship between special education teachers' Professional quality of life and psychological needs

\begin{tabular}{|c|c|c|c|c|c|}
\hline \multicolumn{2}{|c|}{} & Success & Relationship & Autonomy & Dominance \\
\hline $\begin{array}{c}\text { Compassion } \\
\text { Satisfaction }\end{array}$ & $\mathrm{r}$ & $-.332^{*}$ & $-.375^{*}$ & $-.403^{*}$ & $-.344^{*}$ \\
\cline { 2 - 6 } & Sig. & .001 & .001 & .001 & .001 \\
\hline \multirow{2}{*}{$\begin{array}{c}\text { Burnout } \\
\text { Compassion } \\
\text { Fatigue }\end{array}$} & $\mathrm{r}$ & $.507^{*}$ & $.526^{*}$ &, $557^{*}$ & $.503^{*}$ \\
\cline { 2 - 6 } \begin{tabular}{l} 
Sig. \\
\cline { 2 - 6 }
\end{tabular} & $\mathrm{r}$ & .001 & .001 & .001 & .001 \\
\hline
\end{tabular}

*sig $<, 05$

The results as to the linear regression analysis carried out to identify the compassion satisfaction score predictive power of grades gained by special education teachers in their psychological needs sub-dimensions are conveyed in Table 2.

Table 2. Multiple regression analysis results regarding the predicting of the Compassion satisfaction by psychological needs

\begin{tabular}{|c|c|c|c|c|c|}
\hline Predictors & B & $\begin{array}{c}\text { Std. } \\
\text { Error }\end{array}$ & Beta & $\mathbf{t}$ & Sig. \\
\hline (Constant) & 50.771 & 1.997 & & 25.420 & .001 \\
\hline Success & .171 & .198 & .111 & .865 & .388 \\
\hline Relationship & -.294 & .255 & -.158 & -1.156 & .249 \\
\hline Autonomy & -.510 & .198 & -.269 & -2.573 & .011 \\
\hline Dominance & -.244 & .106 & -.169 & -2.304 & .022 \\
\hline $\mathrm{R}=.435^{\mathrm{a}}$ & $\mathrm{R}^{2}=.189$ & \multicolumn{2}{|c|}{$F_{(4-233)}=13.575$} & Sig $=.001$ & \\
\hline \multicolumn{6}{|c|}{$\begin{array}{l}\text { Dependent Variable: Compassion Satisfaction } \\
\text { Predictors: (Constant), Success, Relationship, Autonomy, } \\
\text { Dominance }\end{array}$} \\
\hline
\end{tabular}

As can be seen in Table 2, sub-dimensions of success, relationship, autonomy, dominance of psychological needs scale included in the table as independent variants (predictive variants) can significantly predict the total score of compassion satisfaction $\left(\mathrm{R}=.435, \mathrm{R}^{2}=.189\right.$, $\mathrm{F}=13.575, \mathrm{p}<.001$. This pinpoints that the variance of all sub-dimensions of psychological needs scale in the face of the total score gathered from the compassion satisfaction scale is $18.9 \%$. In accordance with the test $t$ concerning independent variables, autonomy, one of the four independent variables, is the strongest negative predictor of compassion satisfaction $(\beta=-.269)$, followed by dominance $(\beta=-.169)$. Success $(\beta=.111)$ and relationship $(\beta=-.158)$ were found not to be remarkable with their compassion satisfaction predictor level of .05 in total.

The results regarding the linear regression conducted to determine the predictor value of burnout property of the scores special education teachers acquired out of psychological needs sub-dimensions are given in Table 3.

In accordance with Table 3 , it is observed that the psychological needs scale in the analysis as independent variables (predictor variables) significantly predicts the total burnout value of the sub-dimensions success, relationship, autonomy and dominance $\left(\mathrm{R}=.610, \mathrm{R}^{2}=.372\right.$,
$\mathrm{F}=34.434, \mathrm{p}<.001)$. This finding shows that all the sub-dimensions of psychological needs scale accounts for the $37.2 \%$ of the variance belonging to the total burnout score. Based on the test $t$ concerning independent variables, autonomy, one of the four independent variables, is the strongest negative predictor of compassion satisfaction $(\beta=.311)$, followed by dominance $(\beta=-.259)$. Success $(\beta=.041)$ and relationship $(\beta=-.090)$ were found not to be remarkable with their compassion satisfaction predictor level of .05 in total.

Table 3. Multiple regression analysis results regarding the predicting of the Burnout by psychological needs

\begin{tabular}{|c|c|c|c|c|c|}
\hline Predictors & B & $\begin{array}{l}\text { Std. } \\
\text { Error }\end{array}$ & Beta & $\mathbf{t}$ & Sig. \\
\hline (Constant) & -6.377 & 2.049 & & -3.112 & .002 \\
\hline Success & .074 & .203 & .041 & .365 & .715 \\
\hline Relationship & .195 & .261 & .090 & .745 & .457 \\
\hline Autonomy & .688 & .203 & .311 & 3.380 & .001 \\
\hline Dominance & .436 & .109 & .259 & 4.008 & .000 \\
\hline $\mathrm{R}=.610^{\mathrm{a}}$ & $\mathrm{R}^{2}=.372$ & \multicolumn{2}{|c|}{$F_{(4-233)}=34.434$} & $\mathrm{Sig}=.001$ & \\
\hline $\begin{array}{l}\text { Depeno } \\
\text { Predict } \\
\text { Domino }\end{array}$ & \multicolumn{5}{|c|}{$\begin{array}{l}\text { Predictors: (Constant), Success, Relationship, Autonomy, } \\
\text { Dominance }\end{array}$} \\
\hline
\end{tabular}

The results regarding the linear regression conducted to determine the predictor value of compassion fatigue property of the scores special education teachers acquired out of psychological needs sub-dimensions are given in Table 4.

Table 4. Multiple regression analysis results regarding the predicting of the Compassion fatigue by psychological needs

\begin{tabular}{|c|c|c|c|c|c|}
\hline \multicolumn{3}{|c|}{ Compassion } & \multicolumn{2}{|c|}{ psychological } & Heeus \\
\hline Predictors & B & Std. Error & Beta & $\mathrm{t}$ & Sig. \\
\hline (Constant) & -50.274 & 2.578 & & -19.502 & .001 \\
\hline Success & -172 & .255 & .077 & .672 & .503 \\
\hline Relationship & 1.229 & .329 & .457 & 3.741 & .001 \\
\hline Autonomy & .133 & .256 & .049 & .521 & .603 \\
\hline Dominance & .091 & .137 & .044 & .669 & .504 \\
\hline $\mathrm{R}=.592^{\mathrm{a}}$ & $\mathrm{R}^{2}=.351$ & $F_{(4-233)}=$ & 1.505 & $\mathrm{Sig}=.001$ & \\
\hline $\begin{array}{l}\text { Depend } \\
\text { Predict } \\
\text { Domina }\end{array}$ & $\begin{array}{l}\text { Variable } \\
\text { (Const }\end{array}$ & $\begin{array}{l}\text { Compassi } \\
n t), \quad S u c c\end{array}$ & $\begin{array}{l}\text { Fatiq } \\
s, \quad R\end{array}$ & ionship, & tonomy, \\
\hline
\end{tabular}

As can be seen in Table 4, sub-dimensions of success, relationship, autonomy, dominance of psychological needs scale included in the table as independent variants (predictive variants) can significantly predict the total score of compassion fatigue $\left(\mathrm{R}=.592, \mathrm{R}^{2}=.351, \mathrm{~F}=31.505\right.$, $\mathrm{p}<.001)$. This finding shows that all the sub-dimensions of psychological needs scale accounts for the $35.1 \%$ of the variance belonging to the total compassion fatigue score. In accordance with the test $\mathrm{t}$ concerning independent variables, relationship $(\beta=.457)$, one of the four independent variables, is the strongest positive predictor of compassion fatigue with success $(\beta=.077)$, autonomy $(\beta=-.049)$ and dominance $(\beta=-.044)$ were found not to be 
remarkable with their compassion fatigue predictor level of .05 in total.

\section{Discussion}

The results reached from the study carried out on special education teachers show that there is a positive strong correlation between four dimensions of psychological needs (success, relationship, autonomy and dominance) and sub-dimensions of professional life quality (compassion fatigue and burnout) and a negative one between the former and compassion satisfaction. In other words, as the level of psychological needs of special education teachers rises, so does the compassion satisfaction level, but burnout and compassion fatigue levels fall. There are also results in similar studies in the literature backing up this finding. Randjelovic and Stojiljkovic [36] concluded that an increased level of psychological satisfaction mitigated burnout level, too. Irrespective of the classroom environment, a working atmosphere that meets the basic psychological needs correlates with high compassion level and low burnout [36] Likewise, Trépanier, Fernet \& Austin [37] found out in a study they conducted that in cases in which psychological needs were not met exhaustion increased. The findings of this study and similar ones of related studies can be efficiently benefitted in order to enhance professional life quality. In this sense, proper working conditions and working environment in which success, relationship, autonomy and dominance expectations of special education teachers can help augmenting professional satisfaction.

The findings regarding the identification of the professional life quality predictors of special education teachers and that make up the core of this study show that the sub-dimensions of psychological needs can significantly predict compassion satisfaction, burnout and compassion fatigue. More explicitly, the results of the interlinear regression analysis conducted over the total score of compassion satisfaction have shown that the psychological needs scale can account for the $18.9 \%$ total compassion satisfaction score of sub-dimensions success relationship, autonomy and dominance. Among the independent variables, the total score of autonomy needs has been found out to be the strongest negative predictor of compassion satisfaction, followed by dominance needs and success as well as relationship needs have been understood not to be significant predictors. These findings pose that autonomy and dominance needs contribute to the compassion satisfaction level of special education teachers by $18,9 \%$. Similarly, according to the findings regarding the burnout scores of these teachers, sub-dimensions of psychological needs account for the $37 \%$ of the burnout variance. Especially except for success and relationship, autonomy and dominance have been observed to be a negative predictor of burnout. In other words, as the level of dominance and autonomy needs of special education teachers rise, so does the burnout level by $37 \%$. The most astonishing finding of this research is about compassion fatigue, stating that the results of interlinear regression analysis as to the prediction of compassion fatigue account for $35 \%$ of the variance in compassion fatigue together with four psychological needs' sub-dimensions. When $t$ attributes relating to the independent variables are analyzed, only the relationship needs were found to be the negative predictor of compassion fatigue and the other sub-dimensions were found to be no significant predictors. In this respect, as relationship needs increase, so does the compassion fatigue. Yeşil et.al [34] found out in their study that the ones who did not engage in the social activities meeting relationship needs experienced compassion fatigue. Considering that social activities provide good group activities and that these activities also provide a convenience for satisfying relationship needs and sharing challenging times of peers, people who involve in social activities can be said to come across less compassion fatigue.

As expected from this study, psychological needs level of special education teachers are significant predictors of professional life quality. The findings reached in this study working basically on the correlation between dependent and independent variables should be delicately and meticulously assessed in that the effects of independent variables on the dependents ones were not taken into account and the findings do not enable to work out a cause and effect relation between variables. From this point of view, the findings of this study have been advocated by the theoretical minds studying professional life quality.

Randjelovic and Stojiljkovic [36] concluded that working conditions favouring autonomy and dominance expectations of teachers are negatively correlated with burnout. In another study, Bartholomew, Ntoumanis, Cuevas, \& Lonsdale, [38] put forward that underestimation in autonomy is a strong predictor of burnout. Autonomy and dominance could be increased through freedom in goal selection and classroom management, allowing teachers to choose their own professional development opportunities and training programs, and giving teachers greater decision making power to develop and implement initiatives $[39 ; 40$; 41]. This in turn raises teachers' compassion satisfaction level while decreasing their burnout levels.

Such suggestions for further researches to come about special education teachers can be made based on the findings of this study: a) In accordance with the results of the study, as psychological needs satisfaction level of special education teachers increase, so does their compassion satisfaction level; whereas their burnout and compassion fatigue levels fall. b) Therefore, studies aiming to satisfy the psychological needs of such teachers are vital. c) Besides, similar studies using more comprehensive samplings, different research patterns and samples 
regarding the causes of the correlations identified in this study can be carried out as well.

\section{REFERENCES}

[1] Bozgeyikli, H. (2016). Examination of Special Education Teachers' Professional Life Quality According to Demographic Features, International Journal of Contemporary Educational Studies (IntJCES), 2(1), 94-110.

[2] Stamm BH (2005). Professional quality of life scale IV tests. Retrieved October 15, 2017, from http://www.proqol.org/ProQol_Test.html.

[3] Coll, K. M., \& Freeman, B. (1997). Role conflict among elementary school counselors: A national comparison with middle and secondary school counselors. Elementary School Guidance \& Counseling, 31, 251-261.

[4] Ducharme, L. J., \& Martin, J. K. (2000). Unrewarding work, coworker support, and job satisfaction. Work and Occupations, 27, (2), 223-243.

[5] Pugliesi, K. (1999). The consequences of emotional labor: Effects on work stress, job satisfaction, and well-being. Motivation and Emotion, 23, (2), 125-154.

[6] Sevimli, F. \& İșcan, Ö. F.(2005). Bireysel ve iș ortamına ait etkenler açısından iş doyumu, Ege Akademic Review Journal of Economics, Business Administration, International Relations and Political Science, 5 (1), 55-64.

[7] Lobban, R. K., Husted, J., ve Farewell, V. T. (1998). A comparison of the effect of ob demand, decision latitude, role and supervisory style on self-reported job satisfaction. Work \& Stress, 12, (4), 337-350.

[8] Martin, U., \& Schinke, S. P. (1998). Organizational and individual factors influencing job satisfaction and burnout of mental health workers. Social Work in Health Care, 28, (2), 51-62.

[9] Um, M., \& Harrison, D. F. (1998). Role stressors, burnout, mediators, and job satisfaction: A stress-strain-outcome model and an empirical test. Social Work Research, 22, (2), 100-115.

[10] Wolpin, J., Burk, R. J., ve Greenglass, E. R. (1991). Is job satisfaction an antecedent or a consequence of psychological burnout? Human Relations, 44, (2), 193-209.

[11] Maslach C, Jackson SE (1981) The measurement of experienced burnout. Journal of Occupational Behavior, 2, 99- 113.

[12] Bozgeyikli, H. (2011). Observation of Turkish school counselor's life quality, International journal of Academic Research, 3(4), 326-331.

[13] Kaya, A. (2010). Isparta ilinde engellilere yönelik hizmet veren kamu ve özel eğitim kurumlarında çalışan meslek gruplarında tükenmişlik düzeyi. Unpublished Master Thesis. Isparta: Süleyman Demirel Üniversitesi Sağlık Bilimleri Enstitüsü.

[14] Veatch J. M. (2006) The impact of new teacher induction programs on feelings of burnout of special education teachers. Unpublished Doctoral Dissertation. USA: Kansas State University Department of Special Education.

[15] Türe, M. E. (2008). Özel eğitim sektöründe çalışan eğitimcilerin tükenmişlik düzeyleri. Unpublished Master Thesis, Maltepe Üniversitesi, Sosyal Bilimler Enstitüsü, İstanbul.

[16] Girgin, G, ve Baysal, A. (2005). Tükenmişlik sendromuna bir örnek: zihinsel engelli öğrencilere eğitim veren öğretmenlerin mesleki tükenmişlik düzeyi. TSK Koruyucu Hekimlik Bülteni, 4 (4), 172-187.

[17] Wisniewski, L. Ve Gargiulo, R. M. (1997). Occupational stress and burnout among special educators: A review of the literature. The Journal of Special Education, 31(3), 325-346.

[18] Ortlepp, K., ve Friedman, M. (2002). Prevalence and correlates of secondary traumatic stress in workplace lay counsellors. Journal of Trauma Stress, 15(3), 213-222.

[19] Pearlman, L.A. ve MacIan, P.S. (1995). Vicarious traumatization: An empirical study of the effects of trauma work on trauma therapists. Professional Psychology: Research and Practice, 26, 558-565.

[20] Maslach, C. (2003). Job burnout: New directions in research and intervention. Current Directions in Psychological Science, 12, 189-192.

[21] Maslach, C., Jackson, S. E., ve Leiter, M. (1996). Maslach Burnout Inventory manual (3rd ed.). Palo Alto, CA: Consulting Psychologists Press.

[22] Maslach, C., Schaufeli, W. B., ve Leiter, M. P. (2001). Job burnout. Annual Review of Psychology, 52, 397-422.

[23] Kuzgun, Y. (2000). Meslek danışmanlığı. Ankara: Nobel Yayınlar1.

[24] Retniham, S. G. \& Ismail, M. (2008). Constructs of quality of work life: A perspective of information and technology professionals. European Journal of Social Sciences, 7(1), 58-70.

[25] Şat, A., Doğan, H. \& Amil, O. (2015). Investigation of Psychological Needs And Job Satisfaction of Academicians Are Working In Universities In Terms of Some Variables: Kayseri Sample. OPUS- International Journal of Society Researches, 5(8), 112-132.

[26] Glasser, W. (2010). Choice theory: A new psychology of personal freedom. Harper Collins.

[27] Burger, J. M. (2006). Personality, Istanbul: Kaknüs Yaymlar1.

[28] Heckert, T.M., Cuneio, G., Hannah, A.P., Adams, P.J., Droste, H.E., Mueller, M.A., Wallis, H.A., Griffin, C.M., \& Roberts, L.L. (2000). Creation of a new needs assessment Questionnaire. Journal of Social Behavior and Personality, $15,121-136$

[29] Ryan, R. M., \& Deci, E. L. (2000). Self-determination theory and the facilitation of intrinsic motivation, social development, and well-being. The American Psychologist, 55(1), 68-78. https://doi.org/10.1037/0003-066X.55.1.68

[30] Sheldon, K. M., \& Bettencourt, B. (2002). Psychological need-satisfaction and subjective well-being within social 
groups. British Journal of Social Psychology, 41(1), 25-38.

[31] Kasser, Davey \& Ryan (1992). Motivation and employee-supervisor discrepancies in a psychiatric vocational rehabilitation setting. Rehabilitation Psychology, 37, 175-187.

[32] Ilardi, B.C., Leone, D., Kasser, T. ve Ryan, R.M. (1993). Employee and supervisor ratings of motivation: Main effects and discrepancies associated with job satisfaction and adjustment in a factory setting, Journal of Applied Social Psychology, 23, 1789- 1805.

[33] Baard, P. P., Deci, E. L., \& Ryan, R. M. (2004). Intrinsic need satisfaction: A motivational basis of performance and weil-being in two work settings. Journal of applied social psychology, 34(10), 2045- 2068.

[34] Yeşil A, Ergün Ü, Amasyalı C, Er F, Olgun NN, Aker AT (2010). Validity and reliability of the Turkish version of the professional quality of life scale. Archives of Neuropsychiatry, 47, 111-117.

[35] Kesici, S. (2008). New psychological needs questionnaire: Confirmatory factor analysis results. Selcuk University Social Science Institute Journal, 20, 493-500.

[36] Randelovic, K., \& Stojiljkovic, S. (2015). Work climate, basic psychological needs and burnout syndrome of primary school teachers and university professors. Teme - Casopis za Drustvene Nauke, 3, 823-844.
[37] Trepanier, S., Fernet, C., \& Austin, S. (2015). A longitudinal investigation of workplace bullying, basic need satisfaction, and employee functioning. Journal of Occupational Health Psychology, 20, 105-116. doi:10.1037/a0037726

[38] Bartholomew, K. J., Ntoumanis, N., Cuevas, R., \& Lonsdale, C. (2014). Job pressure and ill-health in physical education teachers: The mediating role of psychological need thwarting. Teaching and Teacher Education, 37, 101-107. doi:10.1016/j.tate.2013.10.006

[39] Skaalvik, E. M., \& Skaalvik, S. (2014). Teacher self-efficacy and perceived autonomy: Relations with teacher engagement, job satisfaction, and emotional exhaustion. Psychological Reports, 114, 68-77. doi:10.2466/14.02PRO.114k14w0

[40] Janke, S., Nitsche, S., \& Dickhauser, O. (2015). The role of perceived need satisfaction at work for teachers' work-related learning goal orientation. Teaching and Teacher Education, 47, 184-194. doi:10.1016/j.tate.2015.01.009

[41] Paradis, A., Lutovac, S., \& Kaasila, R. (2015). A Canadian teacher's perceived autonomy and self-confidence in the midst of an educational reform. Problems of Education in the 21st Century, 66, 42-52. 